\title{
上腕骨頸部骨折に対する螺線ピンの使用経験
}

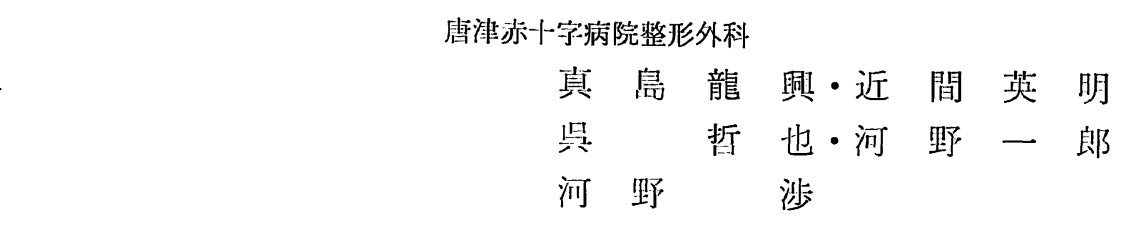

\section{Surgical Treatment for Fracture of the Humeral Neck with Spiral Pin}

\author{
by \\ T. Mashima, H. Chikama, T. Kure, \\ I. Kohno and W. Kawano \\ Orthopaedic surgery, Karatsu Redcross Hospital, Saga
}

\begin{abstract}
Six cases with the fractures of the humeral neck were surgically treated with a spiral pin in our clinic and four of them were followed. The average follow-up time was about 7 months (ranged from 4 months to 10 months).

The average degree of motion of the shoulder joint after operation is as follows124 degrees of flexion, 123 degrees of abduction, 48 degrees of extension, 48 degrees of external rotation and 92 degrees of internal rotation. All of them were satisfied with the result. Internal fixation with a spiral pin gives rigid fixation and therefore allows early movement of the shoulder joint. It is concluded that the spiral pin is a good fixation device for the humeral neck fracture.
\end{abstract}

\section{はじめに}

1980 年, 矢野らは上腕骨頸部骨折に対し 螺線ピン を用いて骨折部を王迫固定し，早期に関節の運動を行 い，良好な成績を修めたと報告している，我々は最 近, 上腕骨頸部骨折の6 例に対し螺線ピンによる内固 定を行い，比较的良好な結果が得られたので報告す る.

$$
\text { 対 }
$$

象

症例は炤和 56 年 9 月より昭和 57 年 6 月の間に螺線 ピンによる内固定をうけた 6 例（男性 1 例, 女性 5 例) で, 受簐洔年令は 52 91才 (平均 78 才) であっ た（表 1 ).

Neer による骨折の分類では, Group I が 1 例, 2 part fracture である Group II が 1 例, Group III が 3 例, 3 part fracture で Group VI が 1 例 であった（表 2 ).
表 1 調 监 対 象

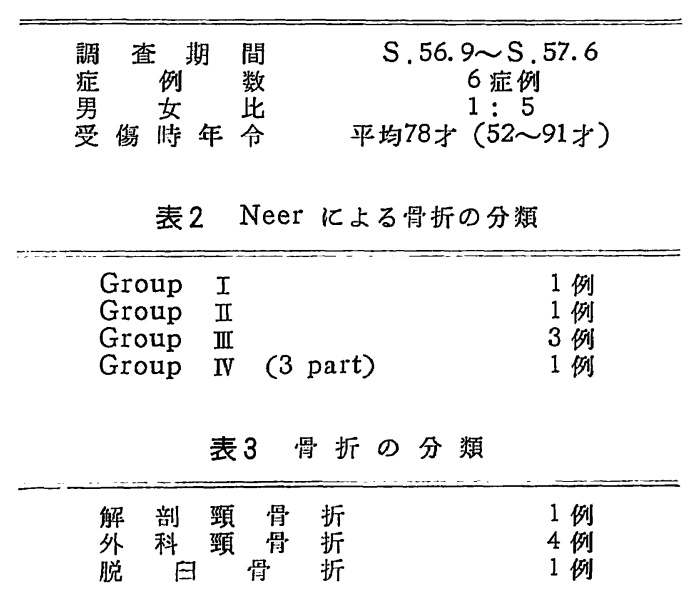

骨折の種類は解剖頸骨折 1 例, 外科頸骨折 4 例, 脱 且骨折 1 例であった（表 3 ). 


\section{固 定 材 料}

四 1 左は螺線ピン, ナット用レンチおよびピンの捻 じ込み用T字型レンチである. 螺㑇ピンの先端部は店 さ $4 \mathrm{~cm}$, 外径 $8 \mathrm{~mm}$ の螺腺状になっている（図 1 中). ピンの未梢侧 $10 \mathrm{~cm}$ はネジ山がつけられ，ワッ シャー，斜めブロックを介してナットにより骨折部を 圧迫できるようになっている（図 1 石）。

\section{手術方 法}

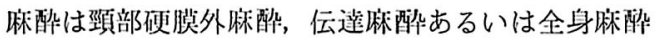
を用い，上腕部に駆血带を使用した．まず皮切を加え る前に透視下に整復位が得られることを確認した。

手術操作であるが，上腕骨顆上部を展開して对頭䔰 より 1〜2 cm 近位部にドリルで孔をあけ，図 2 上の

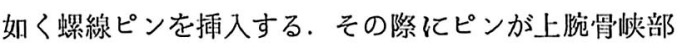
を通過し難い時にのみリーミングを行っている．次 に，透視下に整復位を保持し螺線ピンを骨頭内に捻じ 込みナットを絃めて骨折面を圧迫する.ネジ山の余分 な部分は切除する (図 2 ).

骨折部を展開したものはなく，全例䦥鎖的飞骨接合 術を行った。手術時間は平均 51 分, 出血量は平均 33 grであった.

\section{後療法}

原則として次のように行っている. 術直後より 3 角 巾のみにて固定し，術後第一日目より内・外施運動以 外の肩関節の自・他動運動㧍よび肘関節の自動運動を 開始している. 術後 3 週より 3 角门を除去し，肩関節 の内・外施迎動および pulley などによる訓練を開炲 している.

\section{症例}

(1) 52 才，男性，左上焥骨外科頸骨折

単車で左折中に転倒し受伤. 受傷後 4 日目に硬麻下 に骨接合術を行った，術後 6 力月にて骨痖合良好で連 動恃疼痛もなく，可政域屯届曲 $140^{\circ}$ ，外転 $155^{\circ}$ ，外 旋 $60^{\circ}$ と良好となったため拔釗した（図 3 ).

(2) 80 才，女性，右上腕骨外科頸骨折 玄関の上り口を踏み外して右扁より枟倒し受傷. 受 儩後 6 日目に全瞅下に骨接合術を行った．術直後より 上腕骨々頭はやや内反位に固定されているが, 術後10 カ月のレ線にて骨痹合は良好で可動域む届曲 $120^{\circ}$,

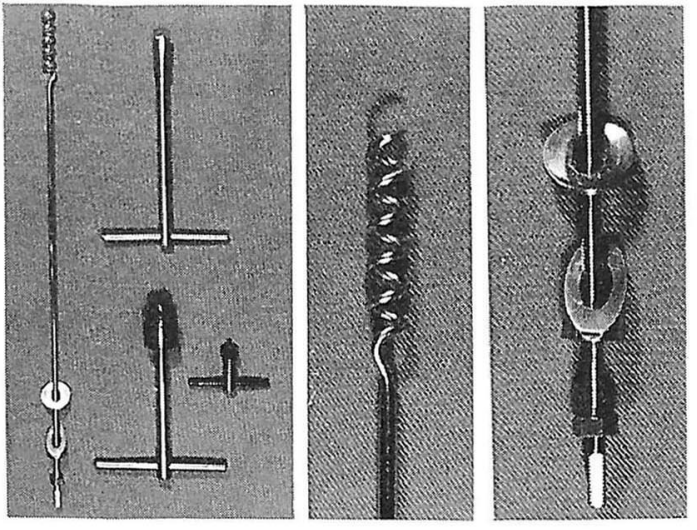

図 1 Spiral pin set
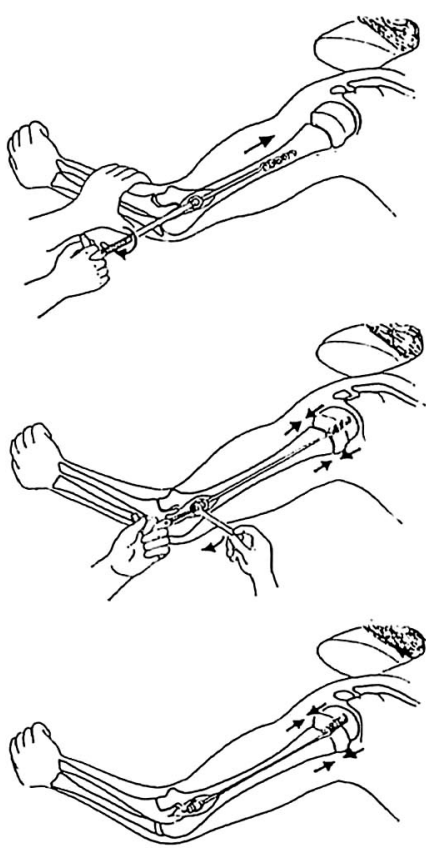

図2手術乎技 (矢野悟・臨整外・15巻 9 号・ $)$

外忶 $105^{\circ}$, 外旋 $60^{\circ}$ と良好であり $\mathrm{ADL}$ 上なんら問 題ない)(図 4).

(3) 76 才，女性. 右上胣骨外科頸骨折 エスカレーターに乘る際転倒し受賃. 受傷後 2 日目 に硬妳下に骨接合術を行った. 術後 9 力月目のレ線に て骨演合は良好であり，また屈曲 $130^{\circ}$ ，外㤝 $135^{\circ}$ ， 外旋 $55^{\circ}$ 之可動域む良好である（図 5).

(4) 91 才, 女性, 右上腕骨外科頸骨折 


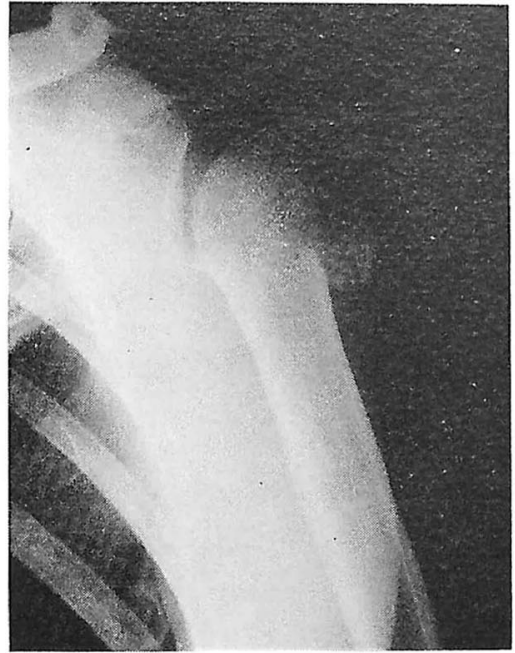

初衫 特

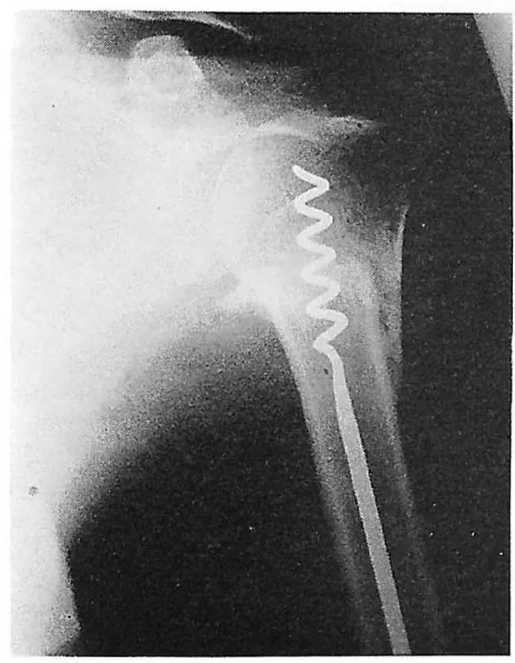

術後 6 力月
図 3

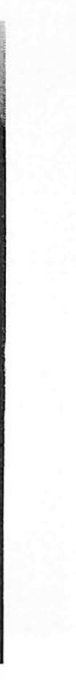

(10)

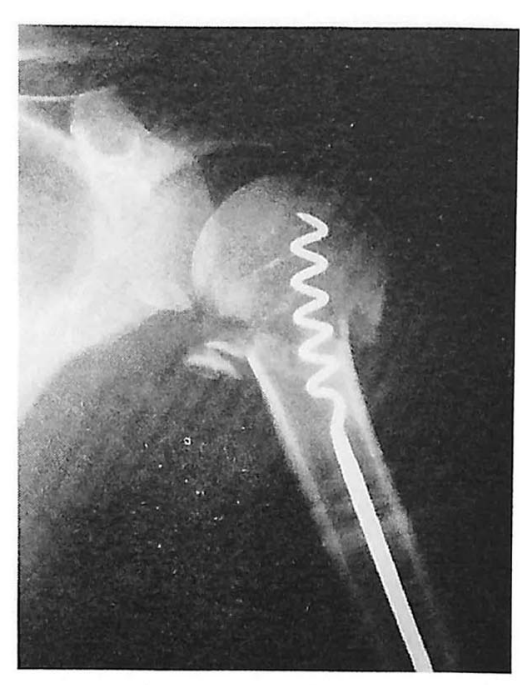

術 直 後

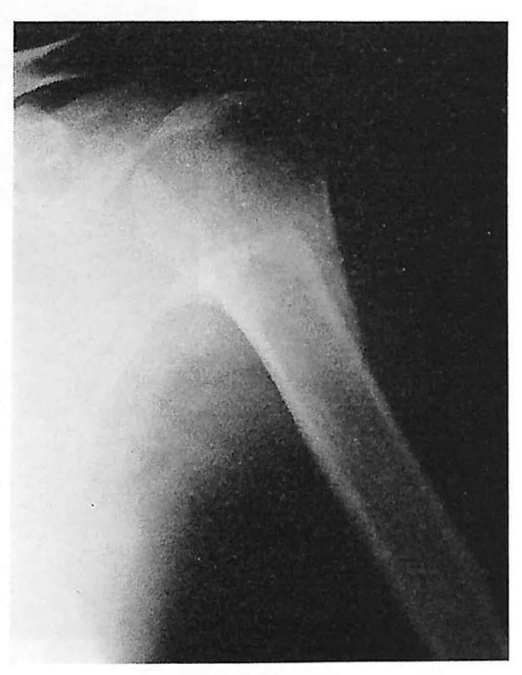

报 剑 後

52 才，男性
畳の上で枟倒し受智. 受傷後4 日目に硬麻下に骨接 合術を行ったが，上腕骨々頭は内反位にてピンの蠌線 部は骨頭内に充分に捻じ込ま机ておらず, 術後 2 週目 に転倒し右肘をついた際に容易に再転位を来たした。 高令を理由に再手術を拒否されたため螺線ピンを㨂入 したまま harging cast 法を行った. 術後 1.5 力月の レ線にて骨折部は再転位したままで仮骨形成が見られ る. その後, 追跡不能となったが電話による問い合わ せでは, 術後 7 力の現在, 結贸・結帯位はなんとか
できるとのととであった（図6).

(5) 77 才，女性，右上脃骨解剖頸骨接

自宅郎下にて枟倒し受㑺. 受㰾後 2 日目に全麻下に 螺線ピンによる内固定を行ったが，入院時より老人性 痴果が著明で後療法が満足にでき奴ま, 術後 2 週に て家族の希望により退院した. 術後 4 力月の現在, ほ ぼ良たきりで日常生活は全て介助を要するが，体位交 換などの際に右肩部を猵がる様子はないとのととであ る(図 7 ). 


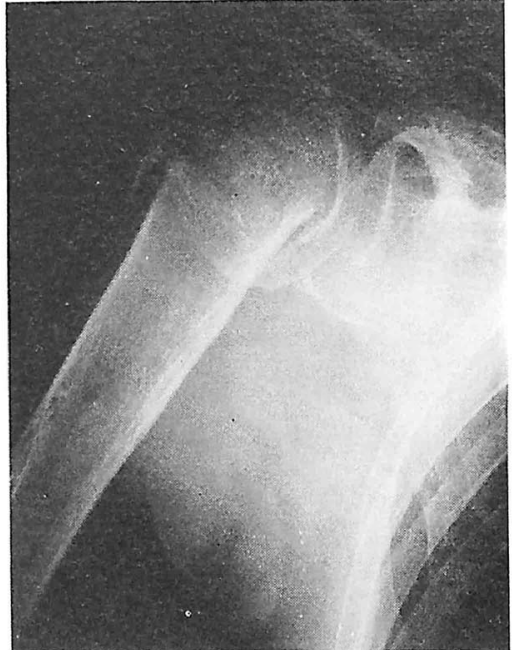

初診 特

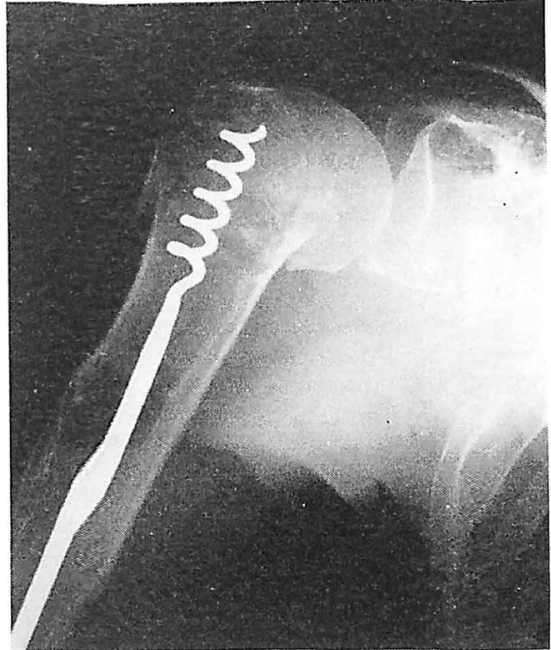

術 直 後

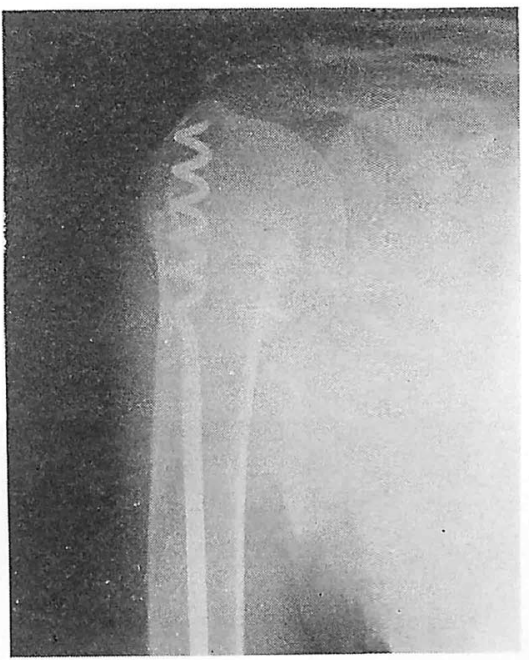

術後 10 力月

図 4

症例 280 才, 女性

(6) 89 才，女性，左肩関節脱田胃折

歩行中に転倒し受傷. 受佰後 2 日目に全䏫下に門鎖 的に脱曰を整復し，螺線ピンによる内固定を行った. 術後 3 週間は Desault 法による包帯固定を行った. 術後 4 力月の現在，骨瘟合は良好であり，可動域も屈 曲 $105^{\circ}$, 外転 $95^{\circ}$, 外旋 $30^{\circ}$ と比較的良好であり疼 痛むなく，結彭・結带む充分に可能である（図 8 ).

$$
\text { 考案 }
$$

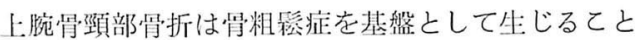

が多く，若年者では稀であり50才以後に多く見られ る. 我々の症例でむ全例 50 才以上（平均 78 才）であ り，6 例中 5 例が女性であった．彷来，これらの症例 の多くは hanging cast 法や 3 角门固定などの梠存 的療法により比較的良好な結果が得られている。しか し骨片の転位が大きく保存的には整復が困難な症例， 骨折かぶ unstable で整復位保持が困難な症例など钼血 的整復および内固定を必要とする症例む稀ならず見ら れる.しかし従来の螺子, Rush pin, plate などによ る内固定では骨折部を展開する必要がある。またこの 


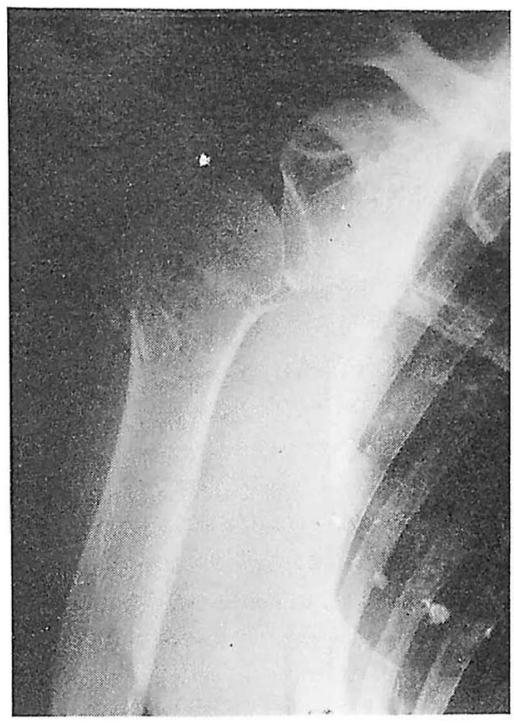

初亮特

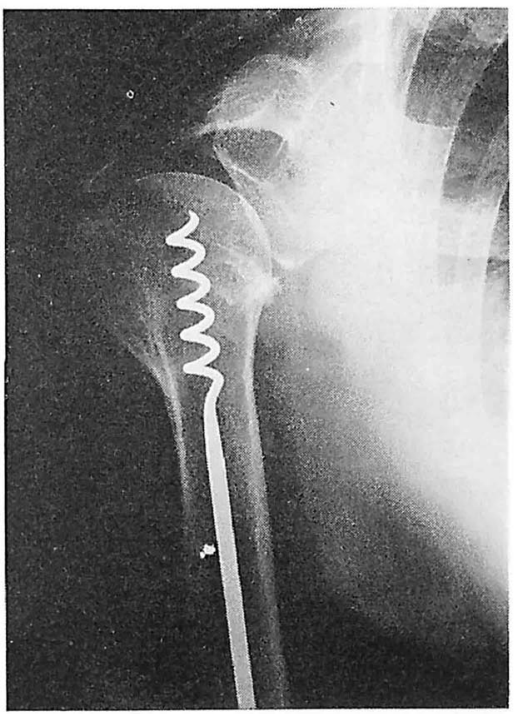

術後 9 力月

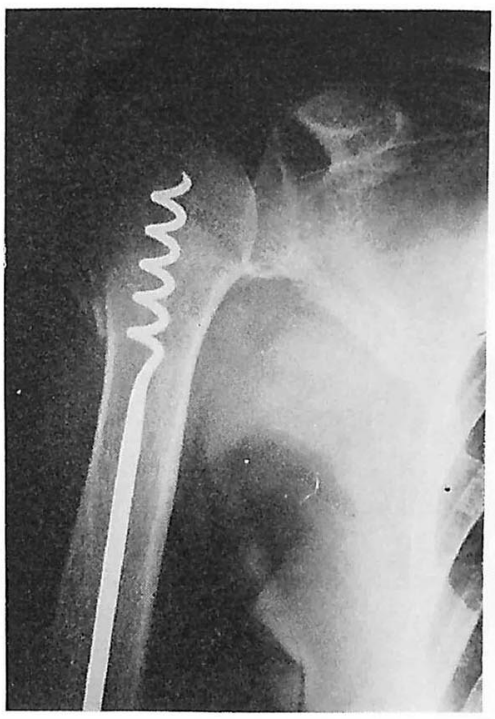

術 直 後

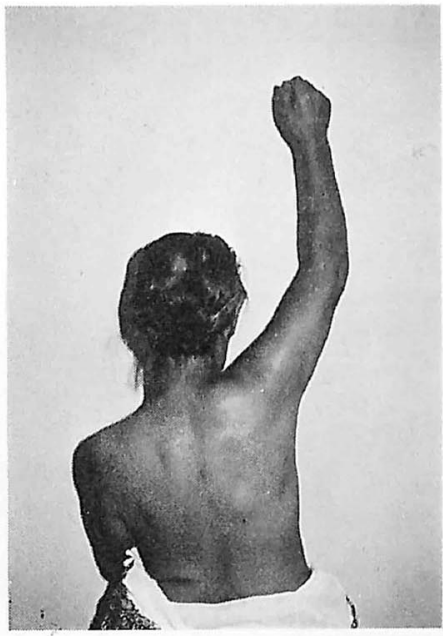

図 5 症例 376 才, 女性
骨折の基盤となっている osteoporosis のために充分 な固定が得られず，外固定を必要とするととが多い， そのために早期に運動ができず肩関節の拘縮を残すと とが多い.

1980 年, 矢野らは上栬骨頸部骨折の 8 症例に対し, 独自に開発した螺線ピンを用いて骨折部を王迫固定し 早期に関節の運動を行い，良好な成績を修めたと報告
している，我々は上焥骨頸部骨折の 6 症例に対し，矢 野らが考案した螺線ピンによる内固定老閉鎖的に行っ た，骨折部の固定性は良好で，脱臼骨折の 1 例を除き 術翌日より肩・肘の運動を開炲した. 6 症例のうち, 追跡調查が可能であった 4 症例（症 例 (1)，(2)，(3)， (6)）の肩関節の可動域の平均值は, 前方挙上 $124^{\circ}$, 外転 $123^{\circ}$, 後方挙上 $48^{\circ}$, 外旋 $48^{\circ}$, 内旋 $92^{\circ}$ とお 


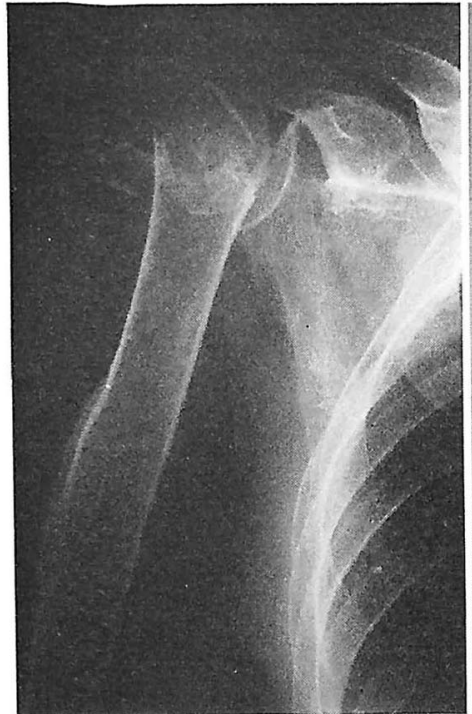

初 診

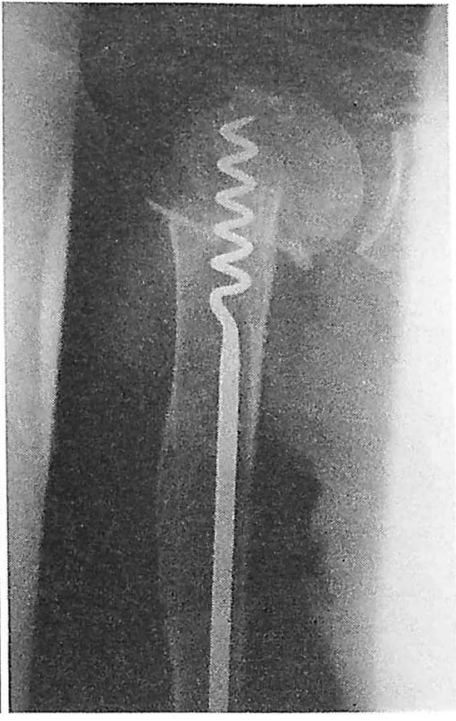

術直 後

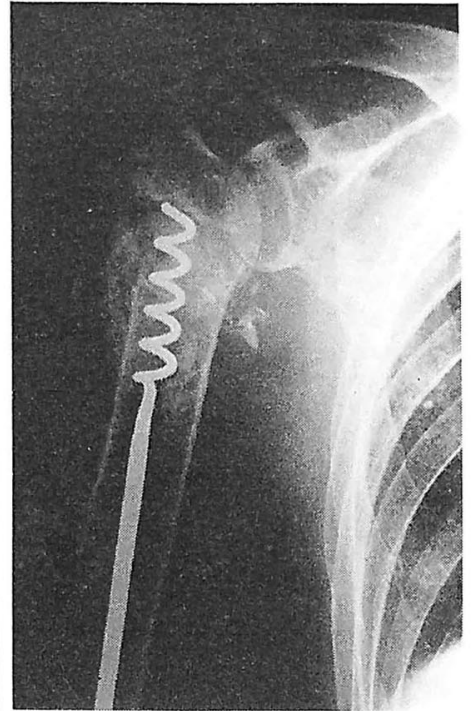

術後 1.5 力月

図 6 剖例 491 才, 女性

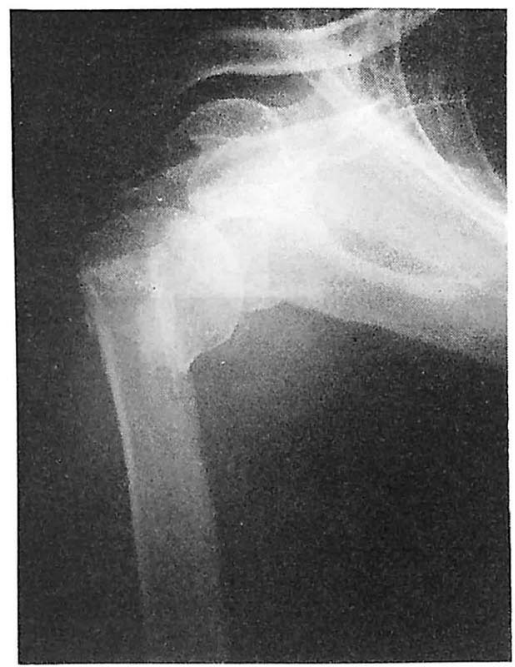

初䜌猔

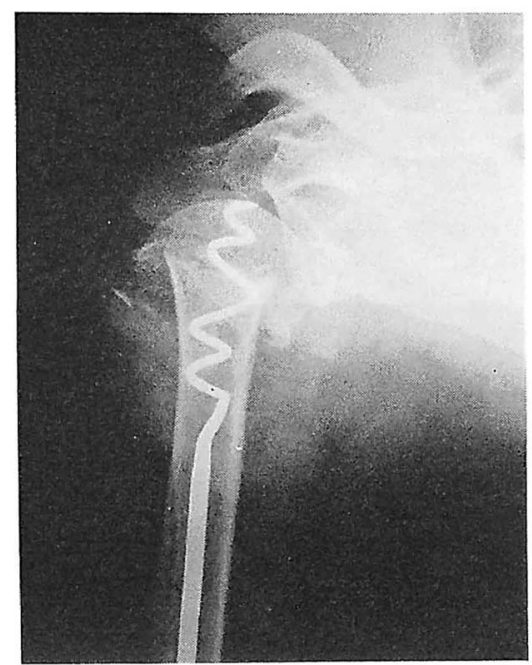

術 直 後

図7 症例 577 , 女性

おむね良好な結果が得られた。

また，老人性痨果などにより患者の理解・協力が得 られず hanging cast 法が困難な症例や長期の卧床 を必要とする卒引療法が適応となるような症例では， 手術侵裂・抜金の問題はあるにしても，患者の負担は 軽くまた早期により良好な可動域が得られると思われ る.
このように，矢野らが開発した螺線ピンは上腕骨頸 部骨折の内固定材料として適していると思われる。今 後, 更に追跡調査を行い骨折の分類等による適応の検 討が必要である.

$$
\text { ま と め }
$$

1.上腕骨頸部骨折 6 症例に対し螺線ピンによる内 


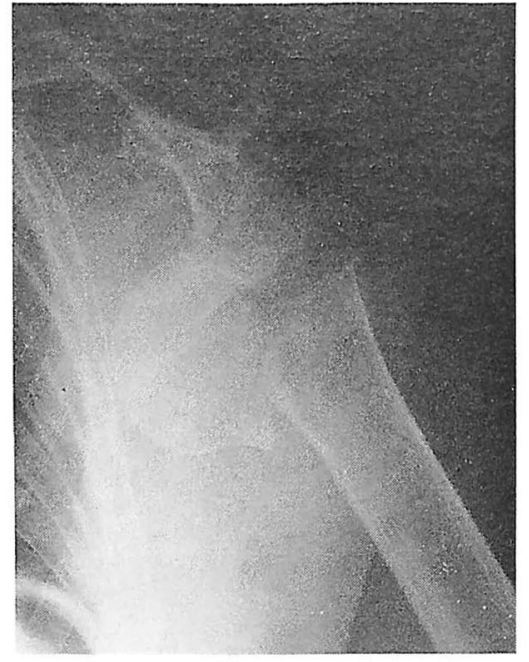

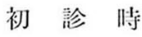

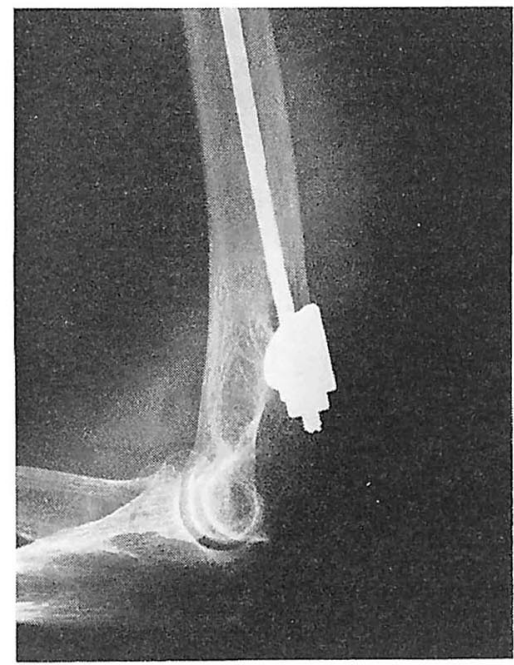

術直 後

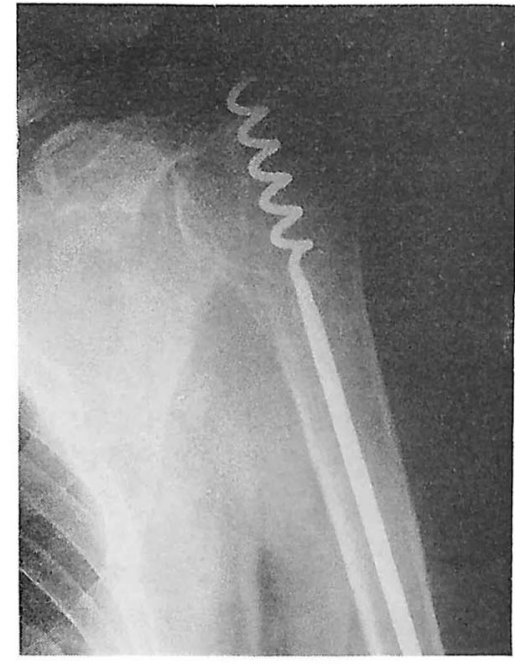

術 直 後

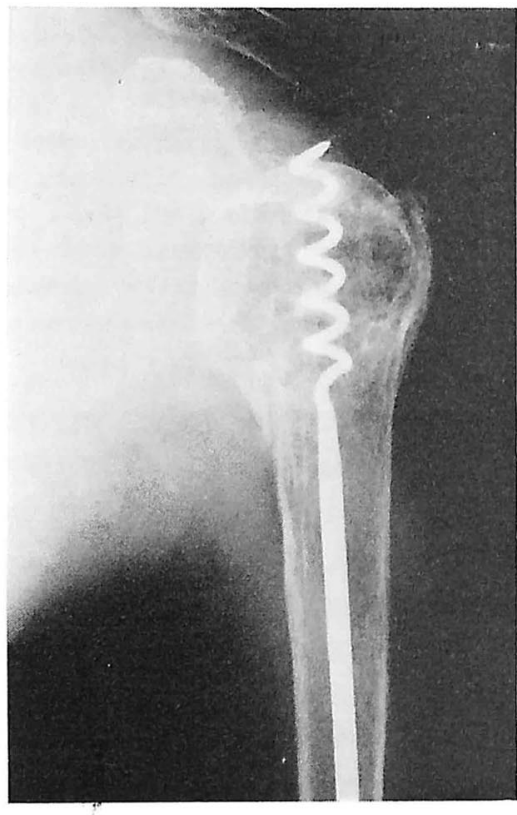

術後 4 力月

図8 症例 6 89才, 女性

固定を行った。

2. 骨折部の固定性は良好で早期運動が可能であ りおおむね良好な結果が得られた.

3. 今後, 更に追跡調査を行い骨折の分類等による 適応の検討が必要である.

文献

1) 岩淵 亮: 肩関節 ·上腕骨近位端（骨折・脱臼 シリーズ) 荻㕩医学, 19: 909-919, 1976.

2) 川崎修：上腕骨上端部骨折について. 整形外 科と災砉外科，27：73-76, 1978.

3) 功能重雄：上肢骨折の統犃的微察. 整形外科と 
災华外科，28：429-431，1980.

4）宮城成圭：上腕骨外科頸骨折および脱日骨折の 治统. 災㕩医学, 14: 379-387, 1973.

5) Neer, C. S. II: Displaced Proximal Humeral Fractures. J. Bone Joint Surg. 52-A:
1077-1103, 1970.

6）西尼沿彦：上胞骨上位端骨折の治療成績。整形 外科と災管外科, 29: 138-141，1980.

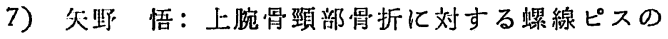
使用経騟．嵒整外，15：883-891，1980。 